RESEARCH REPORT

\title{
Occupational mobility and risk factors in working men: selection, causality or both? Results from the GAZEL study
}

\author{
C Ribet, M Zins, A Gueguen, A Bingham, M Goldberg, P Ducimetière, T Lang
}

J Epidemiol Community Health 2003;57:901-906

See end of article for authors' affiliations

\section{Correspondence to:}

Dr C Ribet, INSERM U258,

16 Avenue Paul Vaillant-

Couturier, 94807 Villejuif

Cedex, France,

ribet@vjf.inserm.fr

Accepted for publication 8 April 2003

\begin{abstract}
Objective: To explore the relation between risk factors (RF) and occupational mobility in working men. Setting: 20000 volunteers working at the French National Electricity and Gas Company (GAZEL cohort). Participants: Men aged 43 to 53 years in 1992.

Design: Three designs were used for analysis. (1) The association between occupational mobility experienced before 1992 and RF reported at that date was analysed among 10383 men. (2) The predictive role of RF on occupational mobility over 1992-1999 was studied in a subsample of 4715 men. (3) Reciprocally, occupational mobility in 1985-1992 was analysed in relation to RF changes over 19931999.

Main outcome measures: Self reported smoking status, excessive alcohol consumption, arterial hypertension, and overweight. Occupational mobility defined by any upward transition between senior executives and professionals/middle executives/employees, and workers.

Results: (1) Cross sectionally, non-mobile men as their entry into the company had a higher risk of being smokers, excessive alcohol drinkers, and overweight in 1992 than mobile men. (2) Longitudinally, smokers and excessive alcohol drinkers in 1992 had a higher risk of non-mobility than, respectively, non-smokers and non-excessive alcohol drinkers. (3) Non-mobile men in 1985-1992 had a higher risk of becoming smokers, excessive alcohol drinkers, and hypertensive in 1993-1999 than upwardly mobile men.

Conclusion: These results suggest a complex relation between RF and occupational mobility. A high level of RF, particularly health behaviours, might account for a selection process reducing upward occupational mobility. In turn, a lack of upward occupational mobility might be associated with an increased incidence of RF.
\end{abstract}

A substantial number of studies have reported a strong inverse association of socioeconomic status with mortality and morbidity, in most industrialised countries. ${ }^{1-5}$ Similarly, large socioeconomic inequalities have been found for several risk factors. In France, for example, a higher prevalence of hypertension and cigarette consumption, and a lower physical activity and blood pressure control have been observed among men in lower occupational categories (OCs). ${ }^{4}{ }^{6}$

To better understand the mechanisms involved, the pathways between psychosocial factors and health should be investigated during the life course. ${ }^{7}$ Different theoretical models have been proposed: latency model, pathway model, cumulative model. ${ }^{8-10}$

The role of social mobility as a determinant of health status, between generations (intergenerational mobility) as well as within generations (intragenerational mobility), has been investigated. ${ }^{11-13}$ In the particular case of the relation between intragenerational mobility and risk factors, it was observed that, in a cohort of Scottish men, among upwardly mobile men between their entry into the labour market and the time of the investigation, at least 15 years after, there were significantly fewer smokers than among occupationally stable men. In contrast, no association was reported in this study with levels of diastolic blood pressure, total cholesterol, body mass index, and the prevalence of wine drinkers. ${ }^{14}$ In a cohort of college students, social mobility, assessed by the level of education achieved at the end of university and the OC 10 years later or more, was not related to the incidence of hypertension. ${ }^{15}$

Nevertheless, we are not aware of any protocol studying simultaneously both directions of the relation between occupational mobility and cardiovascular risk factors: on the one hand, a process of social selection related to these cardiovascular risk factors, and on the other hand an influence of occupational mobility on the occurrence of cardiovascular risk factors. The goal of our survey was thus to study the relations between occupational mobility and cardiovascular risk factors with the hypothesis that this relation could be found in both directions. A cross sectional analysis of the relation between occupational mobility since entry into the company and cardiovascular risk factors was performed, followed by two longitudinal analyses: one concerning the possible predictive role of the cardiovascular risk factors on subsequent occupational mobility and one concerning the analysis of the predictive role of occupational mobility on cardiovascular risk factor incidence.

\section{METHODS}

\section{The GAZEL study}

The GAZEL study has been described in detail previously. ${ }^{16}$ Briefly, in 1989, all male workers aged $40-50$ years and all female workers aged 35-50 years, employed by the French National Electricity and Gas Company (EDF-GDF), were invited to participate in a study based on an annually mailed questionnaire. A total of 20624 volunteers participated (44.6\% of the contacted persons), including 15010 men and 5614 women. Since then, a self administered questionnaire has been sent yearly to all volunteers. During the period 1990-1999, the annual participation rate (number of subjects who returned the questionnaire each year among volunteers in 1989 ) was in the range $72.5 \%$ to $87.2 \% .{ }^{16}$

Abbreviations: RF, risk factors; OC, occupational category 
The questionnaire concerns socioeconomic characteristics, occupational conditions such as physical exertion at work, working hours, job satisfaction, psychosocial work environment, smoking status, alcohol consumption, body weight and height, stated cardiovascular risk factors and a list of perceived, diagnosed or treated disorders during the previous 12 months (for example, respiratory, digestive, cardiovascular, and osteoarticular disorders).

OCs were coded according to the INSEE (French National Institute of Statistics and Economic Studies) classification ${ }^{17}$ and were available from the EDF-GDF administrative department since the entry into the company. In our study, three levels were used for men: (1) senior executive and professional, (2) middle executive, (3) employee and worker. Employees and workers were grouped together as no hierarchy could be established between them. ${ }^{17}$ Occupational mobility was defined as the mobility between these three OCs. Within the framework of the study, only upward occupational mobility could be analysed as it is the only one experienced in the company. Thus, upwardly mobile subjects (at least one OC) and stable subjects (OC unchanged) were compared.

Smoking was defined as a consumption of at least one cigarette a day. Excessive alcohol consumption (g/day) was defined as a daily consumption of at least 48 grams (four glasses or more) during the preceding week. Arterial hypertension was based on the answer to the questions "do you or did you suffer from this disorder during the previous 12 months?" Overweight was defined by a body mass index $(\mathrm{BMI}) \geqslant 25 \mathrm{~kg} / \mathrm{m}^{2}$.

Data were available since 1989 for smoking status and arterial hypertension, since 1992 for alcohol consumption, and since 1990 for weight.

\section{Design and data analysis}

Three different approaches were used: a cross sectional and two longitudinal analyses.

\section{Cross sectional association of current risk factors} with previous upward occupational mobility

Men in working activity, aged 43 to 53 years in 1992 and for whom mobility since their entry into the company could be assessed were selected among the GAZEL cohort. Subjects who were senior executives and professionals at their entry were excluded from the analysis as they were not exposed to upward mobility. As a result, 10383 men were included in the analysis. Upward occupational mobility (between entry into the company and 1992) was thus studied in the relation to risk factors in 1992. Risk factors were used as dependent variables and occupational mobility as independent variable.

\section{Longitudinal relation between risk factors and} subsequent upward occupational mobility

Men in working activity, aged 43 to 53 years in 1992 and for whom occupational mobility could be assessed during the period 1992 to 1999 were selected. Senior executives and professionals in 1992 could not experience upward mobility and were thus excluded. As a result, 4715 men were included in the analysis of the predictive role of risk factors in 1992 on subsequent upward occupational mobility (assessed during the time period 1992 to 1999). Mobility was used as the dependent variable and each risk factor as an independent variable.

\section{Longitudinal analysis of upward occupational} mobility and risk factor incidence

The analysis concerned the predictive role of upward occupational mobility (during the period 1985 to 1992) on risk factor incidence (during the period 1993 to 1999). Men in working activity, aged 43 to 53 years in 1992 and for whom mobility could be assessed were selected. Again senior executives and professionals in 1985 were excluded.

To define risk factor incidence, the following criteria were used. If data on risk factors were missing at least one year during the time period 1993 to 1999, subjects were excluded. Non-smokers, non-excessive alcohol drinkers (that is, moderate consumers or abstinents), men with "normal" weight $\left(<25 \mathrm{~kg} / \mathrm{m}^{2}\right)$ and normotensive subjects between 1985 and 1992 were selected. Incidence of a risk factor was defined by the report of smoking, excessive alcohol consumption or overweight on five occasions between 1993 and 1999, or arterial hypertension at least once between 1993 and 1999. As a result, 4268, 4452, 2309, 5663, men were included respectively in the analysis of smoking, excessive alcohol consumption, overweight, and arterial hypertension. Risk factors were used as dependent variables and mobility as independent variable.

\section{Statistical methods}

Associations between qualitative variables were tested using the $\chi^{2}$ statistic. In both the cross sectional and the second

\begin{tabular}{|c|c|c|}
\hline & Number & $\%$ \\
\hline \multicolumn{3}{|l|}{ Occupational category at entry into the company } \\
\hline Middle executive & 1101 & 10.6 \\
\hline Employee/worker & 9282 & 89.4 \\
\hline \multicolumn{3}{|l|}{ Occupational category in 1992} \\
\hline Senior executive and professional & 2991 & 28.8 \\
\hline Middle executive & 5987 & 57.7 \\
\hline Employee/worker & 1405 & 13.5 \\
\hline \multicolumn{3}{|l|}{ Occupational mobility between entry and 1992} \\
\hline \multicolumn{3}{|l|}{ Upwardly mobile } \\
\hline Middle executive to senior executive and professional & 609 & 5.9 \\
\hline Employee/worker to senior executive and professional & 2382 & 22.9 \\
\hline Employee/worker to middle executive & 5495 & 52.9 \\
\hline \multicolumn{3}{|l|}{ Non-mobile } \\
\hline Middle executive & 492 & 4.8 \\
\hline Employee/worker & 1405 & 13.5 \\
\hline Smokers in 1992 (yes) & 2511 & 24.5 \\
\hline Excessive alcohol consumption in 1992 ( $\geqslant 48 \mathrm{~g} /$ day) (yes) & 650 & 6.9 \\
\hline Arterial hypertension in 1992 (yes) & 1144 & 11.0 \\
\hline Overweight in $1992\left(\mathrm{BMI} \geqslant 25 \mathrm{~kg} / \mathrm{m}^{2}\right)$ (yes) & 5405 & 55.1 \\
\hline
\end{tabular}


Table 2 Risk factor prevalence in 1992 in 10383 men of the GAZEL study according to their upward occupational mobility between entry into the company and 1992

\begin{tabular}{|c|c|c|c|c|}
\hline \multirow[b]{2}{*}{ Risk factors in 1992} & & \multicolumn{2}{|c|}{ Upward occupational mobility between entry and 1992} & \multirow[b]{2}{*}{ p Value } \\
\hline & & Yes (reference) & No & \\
\hline \multirow[t]{2}{*}{ Smoking } & Prevalence $(95 \% \mathrm{Cl})$ & 24.1 (23.1 to 25.0$)$ & $26.3(24.3$ to 28.3$)$ & $<0.05$ \\
\hline & OR $(95 \% \mathrm{Cl})^{*}$ & 1.0 & $1.2(1.0$ to 1.3$)$ & $<0.05$ \\
\hline \multirow{2}{*}{ Excessive alcohol consumption ( $\geqslant 48 \mathrm{~g} /$ day) } & Prevalence $(95 \% \mathrm{CI})$ & $6.6(6.1$ to 7.2$)$ & $8.3(7.0$ to 9.6$)$ & $<0.02$ \\
\hline & OR $(95 \% \mathrm{Cl})^{*}$ & $1.0^{\circ}$ & $1.3(1.1$ to 1.6$)$ & $<0.05$ \\
\hline \multirow[t]{2}{*}{ Arterial hypertension } & Prevalence $95 \%(95 \% \mathrm{Cl})$ & $10.8(10.2$ to 11.5$)$ & $11.8(10.4$ to 13.3$)$ & $<0.23$ \\
\hline & OR $(95 \% \mathrm{Cl})^{*}$ & 1.0 & $1.2(1.0$ to 1.4$)$ & $<0.06$ \\
\hline \multirow[t]{2}{*}{ Overweight $\left(\mathrm{BMl} \geqslant 25 \mathrm{~kg} / \mathrm{m}^{2}\right)$} & Prevalence $(95 \% \mathrm{CI})$ & $54.7(53.6$ to 55.8$)$ & $57.1(54.8$ to 59.4$)$ & $<0.08$ \\
\hline & OR $(95 \% \mathrm{Cl})^{*}$ & 1.0 & $1.2(1.0$ to 1.3$)$ & $<0.05$ \\
\hline
\end{tabular}

longitudinal analyses, a multivariate model (logistic regression) was used to assess the independent effect of mobility on each risk factor prevalence or incidence, respectively, independently of age in 1992 and OC (at entry into the cross sectional part and in 1985 in the longitudinal part). In the first longitudinal analysis, a multivariate model (logistic regression) was used to assess the independent effect of each risk factor on mobility independently of age and OC both in 1992.

Calculations were carried out using the SAS and BMDP statistical softwares. ${ }^{18} 19$

\section{RESULTS}

Cross sectional association of current risk factors with previous upward occupational mobility

Men were mainly employees or workers at entry into the company and mainly middle executives in 1992. Between these two dates, whatever the OC at entry, upward occupational mobility was $82 \%$ (85\% among middle executives and 55\% among employees/workers). In 1992, 25\% of men were smokers, $7 \%$ were excessive alcohol drinkers, $11 \%$ reported arterial hypertension and 55\% overweight (table 1 ).

In the univariate analysis, smoking and excessive alcohol consumption were less frequent among upwardly mobile men than among non-mobile men: $24.1 \%$ compared with $26.3 \%$ and $6.6 \%$ compared with $8.3 \%$, respectively. A similar trend was observed for overweight $(\mathrm{p}<0.08)$ (table 2$)$.

In the multivariate analysis, after adjusting for age in 1992 and OC at entry into the company, non-mobile men had a significantly higher risk of smoking $(\mathrm{OR}=1.2, \mathrm{p}<0.05)$, excessive alcohol consumption $(\mathrm{OR}=1.3, \mathrm{p}<0.05)$, and overweight $(\mathrm{OR}=1.3, \mathrm{p}<0.05)$. A similar trend was observed for arterial hypertension $(\mathrm{OR}=1.2, \mathrm{p}<0.06)$ (table 2$)$.

\section{Longitudinal relation between risk factors and subsequent upward occupational mobility}

Between 1992 and 1999, upward occupational mobility was found to be $11 \%$ ( $10 \%$ among middle executives and $17 \%$ among employees/workers). In 1992, 23\% of men were smokers, $7 \%$ were excessive alcohol drinkers, $12 \%$ stated to have arterial hypertension and 56\% were overweight (table 3 ).

In the univariate analysis, excessive alcohol drinkers in 1992 experienced significantly more subsequent nonmobility than non-drinkers, $93.3 \%$ and $89.0 \%$ respectively. A similar trend was observed for smoking status $(p<0.10)$ (table 4).

In the multivariate analysis, after adjusting for both age and OC in 1992, smokers and excessive alcohol drinkers in 1992 had a significantly higher risk of non-mobility between 1992 and 1999 than, respectively, non-smokers and nonexcessive alcohol drinkers $(\mathrm{OR}=1.3, \mathrm{p}<0.05$ and $\mathrm{OR}=1.8$, $\mathrm{p}<0.05$ ) (table 4).

\section{Longitudinal analysis of upward occupational mobility and risk factor incidence}

Between 1985 and 1992, upward occupational mobility was $22 \%$ (19\% among middle executives and $34 \%$ among employees/workers). The incidence of smoking, excessive alcohol drinking, overweight, and arterial hypertension

\begin{tabular}{|c|c|c|}
\hline & Number & $\%$ \\
\hline \multicolumn{3}{|l|}{ Occupational category in 1992} \\
\hline Middle executive & 4000 & 84.8 \\
\hline Employee/worker & 715 & 15.2 \\
\hline \multicolumn{3}{|l|}{ Occupational category in 1999} \\
\hline Senior executive and professional & 380 & 8.1 \\
\hline Middle executive & 3740 & 79.3 \\
\hline Employee/worker & 595 & 12.6 \\
\hline \multicolumn{3}{|l|}{ Occupational mobility between 1992 and 1999} \\
\hline \multicolumn{3}{|l|}{ Upwardly mobile } \\
\hline Middle executive to senior executive and professional & 376 & 8.0 \\
\hline Employee/worker to senior executive and professional & 4 & 0.1 \\
\hline Employee/worker to middle executive & 116 & 2.5 \\
\hline \multicolumn{3}{|l|}{ Non-mobile } \\
\hline Middle executive & 3624 & 76.8 \\
\hline Employee/worker & 595 & 12.6 \\
\hline Smokers in 1992 (yes) & 1079 & 23.2 \\
\hline Excessive alcohol consumption in 1992 ( $\geqslant 48 \mathrm{~g} /$ day) (yes) & 289 & 6.7 \\
\hline Arterial hypertension in 1992 (yes) & 546 & 11.6 \\
\hline Overweight in $1992\left(\mathrm{BMI} \geqslant 25 \mathrm{~kg} / \mathrm{m}^{2}\right)$ (yes) & 2553 & 56.2 \\
\hline
\end{tabular}


Table 4 Risk of non-mobility during the period 1992 to 1999 in 4715 men of the GAZEL study according to risk factors in 1992

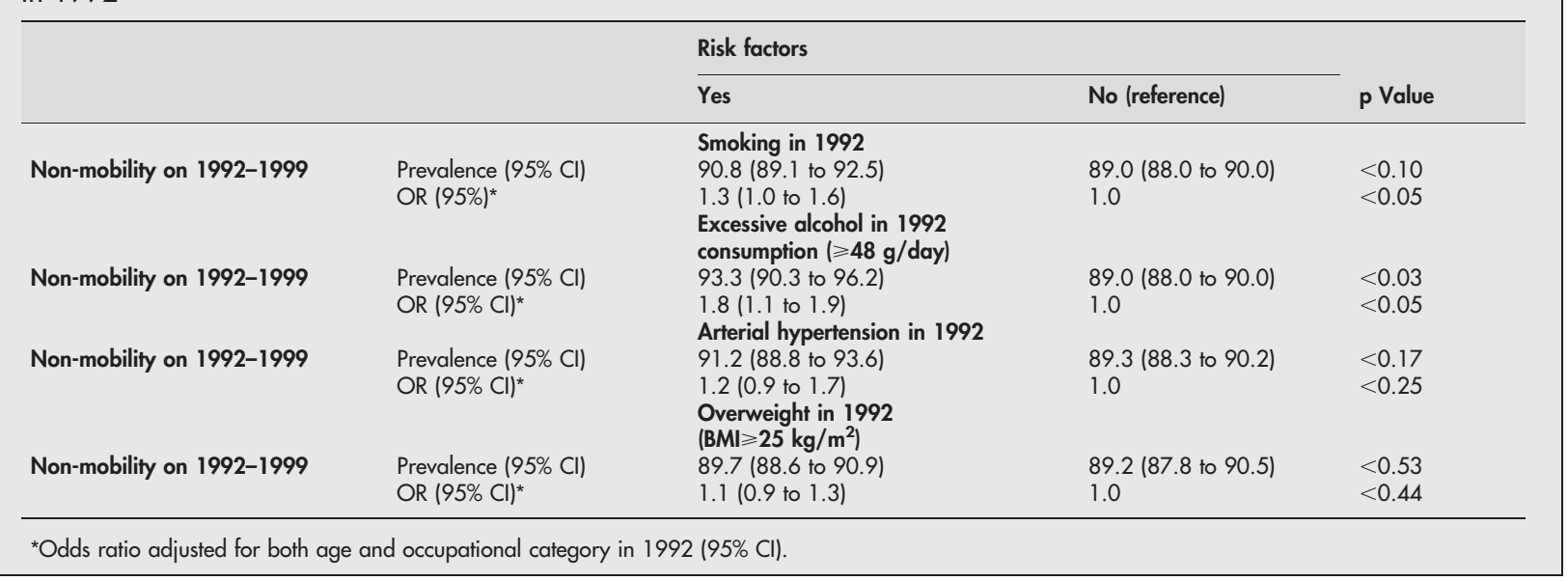

during the period 1993 to 1999 were respectively 4\%, 6\%, $31 \%$, and $14 \%$ (table 5 ).

In the univariate analysis, the incidence of excessive alcohol consumption was significantly lower among upwardly mobile men than among non-mobile men: $4.8 \%$ and $6.7 \%$, respectively. A similar trend was observed for smoking status and hypertension $(\mathrm{p}<0.08$ for both) (table 6).

In the multivariate analysis, after adjusting for age in 1992 and OC in 1985, the incidence of smoking and excessive alcohol drinking was higher in non-mobile men than in mobile men $(\mathrm{OR}=1.5, \mathrm{p}<0.08$ and $\mathrm{OR}=1.4, \mathrm{p}<0.05)$. A similar trend was observed for hypertension $(\mathrm{OR}=1.2$, $\mathrm{p}<0.09$ ) (table 6).

According to the lag-time used, the strength of the relation differed according to the risk factor. When occupational mobility was assessed on the period between 1989 and 1992, incidence of smoking was observed to be higher in stable men $(\mathrm{OR}=2.1, \mathrm{p}<0.05)$. This was not the case for the incidence of arterial hypertension and excessive alcohol consumption $(\mathrm{OR}=1.1, \mathrm{p}<0.65$ and $\mathrm{OR}=1.2, \mathrm{p}<0.54$, respectively). When a longer lag-time was used (mobility assessed on the period 1985-1992), the incidence of smoking was not higher $(\mathrm{OR}=1.4, \mathrm{p}<0.1)$, in contrast with arterial hypertension and excessive alcohol consumption for which incidence was higher $(\mathrm{OR}=1.2, \mathrm{p}<0.07$ and $\mathrm{OR}=1.5$, $\mathrm{p}<0.05$, respectively). Thus, the lag-time was short for smoking and longer for arterial hypertension and excessive alcohol drinking.

\section{DISCUSSION}

The purpose of this study was to analyse the relations between occupational mobility and risk factors in a cohort of working men. Occupational mobility since entry into the company was found to be associated with the risk factors in a cross sectional analysis. Two directions for causality were then tested: on the one hand, the predictive role of the risk factors on subsequent occupational mobility over a period of seven years and on the other hand, the predictive role of occupational mobility on risk factor incidence over a period of seven years. In this sample of active volunteers from the GAZEL study, non-mobile men during their life course had a significantly higher risk of being smokers, excessive alcohol drinkers, and overweight than mobile men. In the longitudinal analysis, smokers and excessive alcohol drinkers had a significantly higher risk of non-mobility than, respectively, non-smokers, and non-excessive alcohol drinkers. Conversely, non-mobile men had a significantly higher risk of becoming smokers, excessive alcohol drinkers, and hypertensive than mobile men in the following years. These results suggest that an excessive risk factor prevalence among non-mobile men might result both from a selection process, some health behaviour leading to a high level of cardiovascular risk factors limiting occupational mobility, and from an effect of mobility in itself, non-mobility leading to an increased risk factor occurrence. Obviously, a common risk factor might lead to both non-mobility and excessive risk factor prevalence.

Some of the study limitations should be discussed. The analysis was performed in a selected population. Indeed, it was found that a greater participation in the GAZEL study was mainly associated with the fact of being a man, of being married, of having three children or more, of being a senior executive, and of having housing provided by the company. ${ }^{20}$ This participation level did not depend on the level of education. In the particular case of risk factors under study, it has been shown, in several studies and in the GAZEL study, that a weaker participation was related to excessive alcohol consumption and to smoking status. ${ }^{20-25}$ In this study, risk factors were assessed by self reporting. As EDF-GDF workers undergo a yearly compulsory medical examination with an occupational physician that includes a physical examination, urine collection, and blood pressure measurement, the GAZEL volunteers are presumably aware of their health problems. Understatement of alcohol consumption is however probable in each socioeconomic group. An underreporting of health problems (such as diabetes or arterial hypertension) in subjects with a low socioeconomic status has been described. ${ }^{26}$ An underestimation of weight and an overestimation of height leading to an underestimation of overweight have been reported in subjects with a high socioeconomic status. ${ }^{27}$ Nevertheless, even if differences in declarations existed between these groups, they would be unlikely to explain the observed relations, as the association with occupational mobility was consistent whatever the studied risk factor. In contrast, OCs were obtained from an external administrative source and thus were unbiased.

The longitudinal analyses were based on short periods during which the probability of mobility was low. Thus, it can be suggested that observed relations were underestimated. Within this company and for this particular generation of men, upward mobility had been very important, more particularly before 1989, because of a socio-professional context very favourable to career evolution. Downward mobility could not be analysed. As a result, generalisation to less specific populations should be made with great care. 
Table 5 Occupational characteristics prevalence and risk factor incidence in men included in the longitudinal analysis (GAZEL study)

\begin{tabular}{|c|c|c|c|c|}
\hline & $\begin{array}{l}\text { Tobacco } \\
\text { consumption } \\
\text { ( } n=4268)\end{array}$ & $\begin{array}{l}\text { Excessive alcohol } \\
\text { consumption } \\
\text { ( } \geqslant 48 \mathrm{~g} / \text { day) }(\mathrm{n}=4452)\end{array}$ & $\begin{array}{l}\text { Arterial } \\
\text { hypertension } \\
(\mathrm{n}=5663)\end{array}$ & $\begin{array}{l}\text { Overweight } \\
\left(B M I \geqslant 25 \mathrm{~kg} / \mathrm{m}^{2}\right) \\
(\mathrm{n}=2309)\end{array}$ \\
\hline \multicolumn{5}{|c|}{ Occupational category in 1985} \\
\hline Middle executive & 79.3 & 81.1 & 78.5 & 81.0 \\
\hline Employee/worker & 20.7 & 18.9 & 21.5 & 19.0 \\
\hline \multicolumn{5}{|c|}{ Occupational category in 1992} \\
\hline $\begin{array}{l}\text { Senior executive and } \\
\text { professional }\end{array}$ & 14.5 & 15.3 & 14.9 & 15.6 \\
\hline Middle executive & 71.6 & 72.2 & 70.7 & 71.6 \\
\hline Employee/worker & 13.9 & 12.5 & 14.4 & 12.8 \\
\hline \multirow{2}{*}{\multicolumn{5}{|c|}{$\begin{array}{l}\text { Occupational mobility between } 1985 \text { and } 1992 \\
\text { Upwardly mobile }\end{array}$}} \\
\hline & & & & \\
\hline $\begin{array}{l}\text { Middle executive to } \\
\text { senior executive and } \\
\text { professional }\end{array}$ & 14.5 & 15.3 & 14.8 & 15.5 \\
\hline $\begin{array}{l}\text { Employee/worker to } \\
\text { senior executive and } \\
\text { professional }\end{array}$ & 0.1 & 0.1 & 0.1 & 0.1 \\
\hline $\begin{array}{l}\text { Employee/worker to } \\
\text { middle executive }\end{array}$ & 6.7 & 6.4 & 7.0 & 6.1 \\
\hline \multicolumn{5}{|l|}{ Non-mobile } \\
\hline Middle executive & 64.8 & 65.7 & 63.7 & 65.5 \\
\hline Employee/worker & 13.9 & 12.5 & 15.4 & 12.8 \\
\hline $\begin{array}{l}\text { Incidence of the risk factor } \\
\text { between } 1993 \text { and } 1999\end{array}$ & 3.5 & 6.3 & 13.8 & 31.0 \\
\hline
\end{tabular}

Unlike the results on alcohol consumption, our results on smoking status were concordant with those observed by Hart et al (a higher risk of being smokers was observed in non-mobile men than in mobile men). ${ }^{14}$ Nevertheless, in their models, these authors did not take into account the effect of the category of origin, as recommended by several authors. ${ }^{28-31}$

Our results suggest two hypotheses. On the one hand, a phenomenon of selection may occur. Some personal habits, such as excessive alcohol consumption or to a lesser extent, tobacco consumption, might slow down the career evolution. For excessive alcohol consumption, occupational stability may be interpreted as the direct consequence of this perceptible high consumption at work on promotion and professional relationships. It seems less probable that tobacco consumption may have a direct effect on the professional evolution. In any case, the effect on mobility would be attributable to the individual behaviour and its social consequences rather than to the high level of risk factors in itself. Nevertheless, a common background factor, for example, personality characteristics, influencing both mobility and tobacco or alcohol consumptions may exist. On the other hand, upward occupational mobility may be protective. Subjects who experienced it might have a lesser risk of risk factors than stable subjects, namely to start excessive alcohol or tobacco consumption and to become hypertensive. These results suggest an effect of stability on behavioural risk factor occurrence, which could be interpreted in different ways. Firstly, stable people could develop an emotional distress resulting from a disturbance of interpersonal relations and modification of social relations at work, leading to a fall of self esteem. Mobility being a form of "reward", the person might perceive his occupational stability as a marker of the lack of recognition from his hierarchy and therefore develop a feeling of imbalance between "provided occupational efforts and obtained rewards". ${ }^{32}$ Lastly, the tendency of stable people to adopt behaviours or to develop hypertension could be the result of a longer exposure to various occupational risk factors, physical as well as psychosocial compared with upwardly mobile people. ${ }^{13} 2933$

An accumulation of risk factors during the life course, leading to an increased mortality among lower social classes has been underlined..$^{10}$ There are two principal conclusions from our study. Our results suggest a complex relation between risk factors and occupational mobility. Some health behaviours leading to a high level of risk factors might account for a selection process reducing upward occupational mobility. In turn, a lack of upward occupational mobility

Table 6 Six years risk factor incidence in men of the GAZEL study according to their upward occupational mobility during the period 1985 to 1992

\begin{tabular}{|c|c|c|c|c|}
\hline \multirow[b]{2}{*}{ Risk factors (incidence between 1993 and 1999) } & & \multicolumn{2}{|c|}{ Upward occupational mobility on 1985-1992 } & \multirow[b]{2}{*}{$\mathrm{p}$ Value } \\
\hline & & Yes (reference) & No & \\
\hline Smoking & $\begin{array}{l}\text { Incidence }(95 \% \mathrm{Cl}) \\
\mathrm{OR}(95 \% \mathrm{CU})^{*}\end{array}$ & 2.5 (1.5 to 3.6$)$ & $3.7(3.1$ to 4.4$)$ & $\begin{array}{l}<0.08 \\
<0.08\end{array}$ \\
\hline Excessive alcohol consumption ( $\geqslant 48 \mathrm{~g} /$ day) & $\begin{array}{l}\text { Incidence }(95 \% \mathrm{Cl}) \\
\text { OR }(95 \% \mathrm{Cl})^{*}\end{array}$ & $\begin{array}{l}4.8(3.4 \text { to } 6.1) \\
1.0\end{array}$ & $\begin{array}{l}6.7(5.9 \text { to } 7.5) \\
1.4(1.0 \text { to } 1.9)\end{array}$ & $\begin{array}{l}<0.03 \\
<0.05\end{array}$ \\
\hline Arterial hypertension & $\begin{array}{l}\text { Incidence }(95 \% \mathrm{Cl}) \\
\text { OR }(95 \% \mathrm{Cl})^{*}\end{array}$ & $\begin{array}{l}12.3(10.4 \text { to } 14.1) \\
1.0\end{array}$ & $\begin{array}{l}14.2(13.2 \text { to } 15.3) \\
1.2(1.0 \text { to } 1.4)\end{array}$ & $\begin{array}{l}<0.08 \\
<0.09\end{array}$ \\
\hline Overweight $\left(\mathrm{BMI} \geqslant 25 \mathrm{~kg} / \mathrm{m}^{2}\right)$ & $\begin{array}{l}\text { Incidence }(95 \% \mathrm{Cl}) \\
\text { OR }(95 \% \mathrm{CI})^{*}\end{array}$ & $\begin{array}{l}30.6(26.6 \text { to } 34.6) \\
1.0\end{array}$ & $\begin{array}{l}31.1(29.0 \text { to } 33.3) \\
1.0(0.8 \text { to } 1.0)\end{array}$ & $\begin{array}{l}<0.83 \\
<0.84\end{array}$ \\
\hline
\end{tabular}

*Odds ratio adjusted for age in 1992 and occupational category in 1985 (95\% confidence intervals). 
might be associated with an increased incidence of risk factors. Our results suggest, in addition, a "vicious circle": the lack of social mobility leading to high levels of risk factors, which in turn might slow down upward social mobility or perhaps, in other contexts, lead to downward mobility.

\section{ACKNOWLEDGEMENTS}

The authors would like to thank the Medical Studies Department of Electricité de France-Gaz de France, as well as the volunteers of the GAZEL cohort, for enabling them to carry out this study.

\section{Authors' affiliations \\ C Ribet, A Bingham, P Ducimetière, INSERM U258, Villejuif, France M Zins, A Gueguen, M Goldberg, INSERM U88, Saint-Maurice, France} T Lang, INSERM U558, Toulouse, France

Funding: this study was supported in part by a grant from the Institut National de Santé et de la Recherche Médicale (INSERM) (Contract no AM606E), from the Direction Générale de la Santé (DGS) and from the Réseau National de la Santé Publique (RNSP). This paper was facilitated by the ESF programme on Social Variations in Health Expectancy in Europe and by the Fondation pour la Recherche Médicale (FRM).

\section{REFERENCES}

1 Desplanques G. L'inégalité sociale devant la mort. In: INSERM, ed. Mortalité et causes de décès en France. Paris: INSERM, 1990.

2 Marmot MG, Davey Smith G, Stansfeld S, et al. Health inequalities among British civil servants: the Whitehall II study. Lancet 1991;337:1387-93.

3 Mackenbach JP. Socio-economic health differences in the Netherlands: a review of recent empirical findings. Soc Sci Med 1992;34:213-26.

4 Lang T, Ducimetiere P, Arveiler D, et al. Incidence, case fatality, risk factors of acute coronary heart disease and occupational categories in men aged 30-59 in France. Int J Epidemiol 1997;26:47-57.

5 Kaplan GA, Keil JE. Socioeconomics factors and cardiovascular disease: a review of the literature. Circulation 1993;88:1973-98.

6 Fouriaud C, Jacquinet-Salord MC, Degoulet P, et al. Influence of socioprofessional conditions on blood pressure levels and hypertension control. Epidemiologic study of 6665 subjects in the Paris district. Am J Epidemiol 1984; 120:72-86

7 Marmot MG, Wilkinson R. Social determinants of health. Oxford: Oxford University Press, 1999

8 Ben Shlomo Y, Kuh D. A life course approach to chronic disease epidemiology: conceptual models, empirical challenges and interdisciplinary perspectives. Int J Epidemiol 2002;31:285-93.

9 Kawachi I, Subramanian SV, Almeida-Filho N. A glossary for health inequalities. J Epidemiol Community Health 2002;56:647-52.

10 Davey Smith G, Hart C. Life-course socioeconomic and behavioral influences on cardiovascular disease mortality: The Collaborative Study. Am J Public Health 2002;92:1295-8.
11 Lundberg $\mathrm{O}$. Childhood living conditions, health status, and social mobility: a contribution to the health selection debate. Eur Sociol Rev 1991;7:149-62.

12 Blane D, Davey Smith G, Bartley M. Social selection: what does it contribute to social class differences in health? J Health Soc Behav 1993;38:376-86.

13 Dahl E. Social mobility and health: cause or effect? More likely that adverse social circumstances cause ill health than the other way around. BMJ 1995;313:435-6.

14 Hart CL, Davey Smith G, Blane D. Social mobility and 21 year mortality in a cohort of Scottish men. Soc Sci Med 1998;47:1121-30.

15 Gillum RF, Paffenbarger RSJ. Chronic disease in former college students. XVII. Sociocultural mobility as a precursor of coronary heart disease and hypertension. Am J Epidemiol 1978;108:289-98

16 Goldberg M, Leclerc A, Bugel I, et al. Cohorte GAZEL 20000 volontaires d'Electricité De France-Gaz De France pour la recherche médicale. Bilan 1989-1993. Paris: INSERM, 1994.

17 Desrosières A, Thévenot L. Les catégories socio-professionnelles. Paris: La Découverte, 2000.

18 SAS. SAS/STAT user's guide, version 6, fourth edn. Cary: SAS Institute, 1989.

19 BMDP Statistical Software. BMDP manual, version 7. Los Angeles: University of California Press, 1992

20 Goldberg M, Chastang JF, Leclerc A, et al. Socioeconomic, demographic, occupational, and health factors associated with participation in a long-term epidemiologic survey: a prospective study of the French GAZEL cohort and its target population. Am J Epidemiol 2001;154:373-84.

21 Janzon L, Hanson BS, Isacsson SO, et al. Factors influencing participation in health surveys. Results from prospective population study 'Men born in 1914' in Malmo, Sweden. J Epidemiol Community Health 1986:40:174-7.

22 Jacobsen BK, Thelle DS. The Tromso Heart Study: responders and nonresponders to a health questionnaire, do they differ? Scand J Soc Med 1988;16:101-4

23 Macera CA, Jackson KL, Davis DR, et al. Patterns of non-response to a mail survey. J Clin Epidemiol 1990:43:1427-30.

24 Klesges RC, Williamson JE, Somes GW, et al. A population comparison of participants and nonparticipants in a health survey. Am J Public Health 1999;89:1228-31.

25 Chevalier A, Luce D, Blanc C, et al. Sickness absence at the French National Electric and Gas Company. Br J Ind Med 1987:44:101-10.

26 Mackenbach JP, Looman CW, Van der Meer JB. Differences in the misreporting of chronic conditions by level of education: the effect of inequalities in prevalence rates. Am J Public Health 1996;86:706-11.

27 Niedhammer I, Bugel I, Bonenfant S, et al. Validity of self-reported weight and height in the French GAZEL cohort. Int J Obes Relat Metab Disord 2000;24:1111-18.

28 Blalock HM. Status inconsistency, social mobility, status integration and structural effects. Am Sociol Rev 1967;32:790-801.

29 Morgenstern H. Socioeconomic factors: concepts, measurement and health effects. In: Ostfeld AM, ed. Workshop on measuring psychosocial variables in epidemiologic studies of cardiovascular disease. Bethesda: National Institutes of Health, 1985.

30 Laslett B. Mobility and work satisfaction: a discussion of the use and interpretation of mobility models. Am J Sociol 1971;77:19-35.

31 Horan PM, Gray BH. Status inconsistency, mobility and coronary heart disease. J Health Soc Behav 1974;15:300-10.

32 Siegrist J. Adverse health effects of high-effort/low-reward conditions. J Occup Health Psychol 1996;1:27-41.

33 Vernon SW, Buffler PA. The status of status inconsistency. Epidemiol Rev 1988;10:65-86. 